\title{
Assessing the effectiveness of land resource management practices on erosion and vegetative cover using GIS and remote sensing techniques in Melaka watershed, Ethiopia
}

\author{
Asnake Mekuriaw ${ }^{1,2^{*}}$
}

\begin{abstract}
Background: Land resource management measures, such as soil bund, trench, check dams and plantation had been practiced in Melaka watershed, Ethiopia since 2010. The objective of this study is to assess the impact of above measures on soil loss rate, vegetative cover and livelihood of the population.

Results: The land cover spatial data sets were created from Landsat satellite images of 2010 and 2015 using ERDAS IMAGINE 2014 ${ }^{\circledR}$. Soil loss rate was calculated using Revised Universal Soil Loss Equation (RUSLE) and its input data were generated from field investigation, satellite imageries and rainfall analysis. Data on land resource of the study area and its impact on livelihood were collected through face-to-face interview and key informants. The results revealed that cropland decreased by $9 \%$ whereas vegetative cover and grassland increased by 96 and 136\%, respectively. The soil loss rate was $19.2 \mathrm{Mg} \mathrm{ha}^{-1}$ year $^{-1}$ in 2010 and $12.4 \mathrm{Mg} \mathrm{ha}^{-1}$ year ${ }^{-1}$ in 2015, accounting to 34\% decrease over 5 years. It may be attributed to construction of soil bund and the biological measures practiced by the stakeholders. Consequently, land productivity and availability of forage was improved which substantially contributed to the betterment of people's livelihood.
\end{abstract}

Conclusions: The land resource management measures practiced in the study area were highly effective for reducing soil loss, improving vegetation cover and livelihood of the population.

Keywords: Melaka watershed, Land use/cover change, Soil loss, RUSLE, GIS and remote sensing

\section{Background}

The land resources such as the soil, vegetation and water are major resources of land to support livelihood of watershed community. They are highly interdependent. A disturbance in any one component is likely to have an impact on the others. For instance, loss of top soil, which is the base for crop cultivation (Keesstra et al. 2016), from cultivated land may force a country to sacrifice resources such as vegetation in order to provide fertile

\footnotetext{
*Correspondence: asnake.mek@gmail.com; asnakem@bdu.edu.et ${ }^{1}$ Natural Resources Management Department, Bahir Dar University, Bahir Dar, P. O. Box 1739, Bahir Dar, Ethiopia

Full list of author information is available at the end of the article
}

land and resettlement areas. When human beings utilize land beyond its capability, it may cause serious environmental disturbance. This process is increasingly evident in the highland of Ethiopia where the increasing human population and dependence on agriculture have intensified land use pressures (Mekuriaw 2006; Oinam et al. 2014). Without proper land management practices, this pressure definitely leads to land degradation (particularly in the form of soil erosion and deforestation), which, in turn, affects the productive and service functions of land as well as the livelihood of the population.

Historically, soil erosion has become a serious problem in many countries (De Graaff et al. 2008; Sisay et al. 2014) 
including Ethiopia (Hurni et al. 2010; Amdihun et al. 2014; Hailu 2015). The annual soil loss rate in Ethiopia is about 852.8 million $\mathrm{Mg} \mathrm{ha}^{-1}$ year $^{-1}$ on the whole land use type (Hurni et al. 2015). Regarding vegetation cover, before the 1950 s about $40 \%$ of Ethiopia was covered by forest, bushes and shrubs (MoNRDEP 1994). However, the forest cover of the country reduced to $6.1 \%$ in 2010 (MoFED 2010) as a result of ever-increasing demands for firewood, construction poles, farm implements, and crop and grazing land to accommodate rapid population growth.

Land degradation coupled with population pressure as well as erratic and unpredictable weather conditions triggered by climate change has severely threatened food security of the Ethiopian highlands. Cognizant of these, the Ethiopian governments took several land resource management measures including construction of soil/ stone bund and terraces on cultivated land, tree plantation on hillsides and marginal lands, water harvesting in drier regions through construction of ponds, diversion drains, and check dams (Asrat et al. 2004). However, the majority of farmers of the Ethiopian Highlands including the study area partially or totally demolished the land management measures practiced in their cultivated lands and in the communal lands (Mekuriaw and Hurni 2015). Consequently, the land resources including the soil had been degraded, reducing crop yields and affecting the livelihoods of the population.

In order to check soil erosion and deforestation, land resource management measures, specifically soil bund, plantation, check dams and trench were implemented and maintained since 2010 in Melaka watershed, located in Kwarit district, west Gojjam administrative zone of Ethiopia. Technical support was provided by the researcher. The bottom-up approach was followed to ensure sustainability of land management measures being practiced. So far no prior study was undertaken on the land resources status and its impact on the livelihood. Therefore, this study was carried out to assess the impact of land resources management measures on soil loss, vegetative cover, and the livelihood of the population in the study area.

\section{Materials and methods}

\section{Description of the study area}

The study was conducted in Melaka watershed covering $1.55 \mathrm{~km}^{2}$, Kwarit district, west Gojjam Administrative zone, Ethiopia. Geographically, the study area extends from $10^{\circ} 58^{\prime} 24.37^{\prime \prime}$ to $10^{\circ} 59^{\prime} 1.57^{\prime \prime} \mathrm{N}$ and $37^{\circ} 24^{\prime} 10.69^{\prime \prime}$ to $37^{\circ} 25^{\prime} 13.81^{\prime \prime} \mathrm{E}$. Its altitude ranges between 2149 and $2441 \mathrm{~m}$ asl. The topography is characterized by plain through variable relief to steep slope. The farmers of the study area depend on mixed farming system including crop production and livestock raising.

\section{Data source}

Changes on land use/cover, vegetation covers and soil loss rate were used as main parameters to assess the effectiveness of land resource management measures practiced in the study area. In addition, the income of the population was considered. Landsat satellite image (https://earthexplorer.usgs.gov, https://libradevelopmentseed.org/) was chosen for mapping the land use/cover of the study area. An input data for soil loss rate estimation was collected from the field (e.g., soil colour), nearby meteorological station, and ASTER Digital Elevation Model (DEM) because it has the same resolution with the Landsat image and freely available (http://asterweb.jpl.nasa.gov/gdem. asp). Socio-economic data were collected through faceto-face interview and key informants using a carefully designed questionnaire. All 121 household heads were physically surveyed in the study area.

\section{Methods \\ Land use/cover mapping}

The term land use describes the type of uses (e.g., forest, residential areas, mining and conservation areas, etc.) to which the land has been subjected, whereas land cover describes the bio(physical) appearance, features and characteristics of that land (Byrne 2001). In the study area the following four major land use types were identified:

1. Croplands used for growing various crops.

2. Settlements the scattered rural settlements those are closely associated with home plots.

3. Vegetation areas covered with dense growth of trees, bushes, woodlands, including eucalyptus trees and Sesbania sesban.

4. Grassland areas used for communal grazing as well as land that has very little grass cover.

Land use/cover spatial database were created using supervised classification because it is more closely controlled by the analyst and it gives more accurate result. This per-pixel image classification methods require training samples, which can be gained from a field visit to selected spots or via visual interpretation of aerial photographs or from Google Earth. In order to map the 2015 land use/cover, 21 patches (cropland), 24 patches (vegetation), 8 patches (settlement area) and 3 patches (grassland) were collected from the study area using a handheld Global Positioning System(GPS)—specifically GPSMAP $^{\circledR} 60 \mathrm{CS} \times$ (Garmin Ltd., Southampton, United 
Kingdom) -with an accuracy of $\pm 3 \mathrm{~m}$. To classify the image of 2010, 21 patches (cropland), 15 patches (vegetation), 5 patches (settlement area) and 5 patches (grassland) were collected using the same GPS. The imageries were classified into four land cover classes based on the training samples signatures.

\section{Accuracy assessment}

Prior to analyze the land use/cover change, user's, producers and overall accuracy of the land cover change area and confidence level should be estimated (Olofsson et al. 2013). For this purpose, 65 referenced data for each year were collected using GPS. An accuracy of a land cover map can be calculated from sample points and presented in the form of error or confusion matrix (GFOI 2013). An error matrix can be reported in terms of sample counts. However, error matrix is usually expressed in terms of the unbiased estimator of area proportion of the error matrix rather than in terms of sample counts (Olofsson et al. 2013). According to GFOI (2013) the sample based estimator for the area proportion (pij), where $i$ denotes the row and $j$ denotes the column in the error matrix, is calculated as:

$$
p i j=w i * \frac{n i j}{n i}
$$

where wi is the ratio of $\mathrm{mi} / \mathrm{mt}$; $\mathrm{mi}$ is the mapped area of land use class $i$; $\mathrm{mt}$ is the total area of the map, nij is the cell value at row $i$ and columun $j ; n i$. is the total sample count of land use class $i$. After this the area of each land use/cover class is estimated based on the reference classification, which can be calculated using the equation proposed by Olofsson et al. (2013) as follows:

$$
p j=\sum_{i=1}^{n} w i * \frac{n i j}{n i} .
$$

$p j$ is category/land use class $j$ based on the reference data.

Then a confidence interval for the estimated area of each land use class is estimated after the standard error of each land use class is calculated. The estimated standard error (SE) of the estimated area proportion (the column total) of each land use class is estimated as (Cochran 1977):

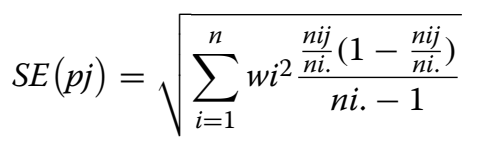

The standard error for estimated area of each land use class was calculated by multiplying the proportion area of a given class by the total map area as proposed by Olofsson et al. (2013) and GFOI (2013). Finally, land use/ cover change was assessed and presented in numeric and graphic forms.

\section{Annual soil loss rate modelling}

In this study the annual soil loss rate was estimated following RUSLE equation using GIS and remote sensing techniques.

$$
\mathrm{A}=\mathrm{R} * \mathrm{~K} * \mathrm{LS} * \mathrm{C} * \mathrm{P}
$$

where $\mathrm{A}=$ predicted soil loss per unit area $\left(\mathrm{Mg} \mathrm{ha}^{-1} \mathrm{year}^{-1}\right)$, $\mathrm{R}=$ rainfall erosivity, dimensionless (number), $\mathrm{K}=$ soil erodibility, $\mathrm{Mg} \mathrm{ha}^{-1}$ year $^{-1}$, $\mathrm{LS}=$ topographic factor, i.e., slope length and steepness, $\mathrm{C}=$ land cover factor, ratio of covered area, vegetation to total area, $\mathrm{P}=$ management practice factor (strip cropping, terracing, etc.).

\section{R-factor (rainfall erosivity)}

Rainfall erosivity is the kinetic energy of rainfall storms to cause soil erosion (Renard et al. 1997). For the Ethiopian highlands, Hurni (1985) developed regression empirical equation.

$$
R=-8.12+0.562 P
$$

where $\mathrm{R}$ is the rainfall erosivity factor (number) and $\mathrm{P}$ is the mean annual rainfall ( $\mathrm{mm}$ ).

We determined the erosivity of the study area using 19 years mean rainfall data (1996-2015) recorded by Gebeze Mariam rainfall station, which have full data set. Finally, the erosivity layer with a cell size of $30 \mathrm{~m}$ was created.

\section{K-factor (erodibility)}

The K-factor indicates the inherent resistance of the soil to particle detachment and transport by water erosion, which describes the susceptibility of the soils to erosion (Renard et al. 1997). Soil erodibility depends on various soil properties like structure, texture, organic maters, colour and permeability. For Ethiopian condition, Hurni (1985) developed K determination based on soil colour estimated by Mansell colour chart (Table 1). Therefore, soil colour was selected to determine the $\mathrm{K}$ value.

To determine the $\mathrm{K}$ values of the study area, 32 soil sample points were selected based on transect walk. The sample points were interpolated using Triangulated Irregular Network technique after the respective K values were assigned to each sampled vector points. Finally, K value layer having a cell size of $30 \mathrm{~m}$ was created (Fig. 1).

\section{LS-factor (topographic factors)}

The local slope gradient (S-factor) represents the gradient that influences flow velocity (Renard et al. 1997) whereas the slope length (L-factor) represents the distance between the point of origin of overland flow to the point where either deposition begins or the flow is concentrated into rills in a defined channel (Wischmeier and Smith 1978). The LS-factor is considered as the first factor controlling soil erosion (Farhan et al. 2013). This 
Table 1 K, C and P factors Hurni (1985)

\begin{tabular}{|c|c|}
\hline \multicolumn{2}{|l|}{ Erodibility } \\
\hline Soil colour & Kvalue \\
\hline Black (e.g. Andosol, Vertisol) & 0.15 \\
\hline Red (e.g. Nitisol) & 0.20 \\
\hline Brown (e.g. Cambisol, Phaeozem) & 0.25 \\
\hline Yellow (e.g. Fluvisol, Xerosol) & 0.30 \\
\hline Management practices (Management) & Pvalue \\
\hline Protected/reforested & 0.50 \\
\hline Terraces & 0.60 \\
\hline Strip cropping & 0.80 \\
\hline Grazing areas & 0.90 \\
\hline Ploughing on contour & 0.90 \\
\hline Ploughing up and down & 1.00 \\
\hline \multicolumn{2}{|l|}{ Cover factor } \\
\hline Land cover & Cvalue \\
\hline Dense forest & 0.001 \\
\hline Dense grass & 0.01 \\
\hline Badlands hard & 0.05 \\
\hline Degraded grass & 0.05 \\
\hline Fallow hard & 0.05 \\
\hline Other forest & 0.05 \\
\hline Sorghum, maize & 0.10 \\
\hline Cereals, pulses & 0.15 \\
\hline Ethiopian tef & 0.25 \\
\hline Badlands soft & 0.40 \\
\hline Fallow ploughed & 0.60 \\
\hline Continuous fallow & 1.00 \\
\hline
\end{tabular}

factor can be measured from the field, which is labour intensive and thus not feasible for estimating LS factor at large size watershed. To solve this problem, a computer program that could generate a grid LS factor from DEM was developed (Wischmeier and Smith 1978).

$$
\begin{aligned}
\mathrm{LS}= & (\text { flow accumulation } * \text { cell size } / 22.1)^{\mathrm{m}} \\
& *\left(0.065+0.045 \mathrm{~S}+0.0065 \mathrm{~S}^{2}\right)
\end{aligned}
$$

where cell size is $30 \mathrm{~m}, \mathrm{~S}=$ slope in per cent/slope steepness, $m$ exponent that depends on slope steepness.

$\mathrm{m}=0.2$ if $\mathrm{S}<1 \%$
0.3 if $\mathrm{S}\left[\begin{array}{ll}1 & 3)\end{array}\right.$

0.4 if $S[35)$

0.5 if $\mathrm{S} \geq 5$

In this study the LS-factor was determined using the above formula. To estimate the $m$ value, exponent that depends on slope steepness, the slope class of the study area was determined using ArcGIS10.2. Approximately $97 \%$ of the study area has slopes of above $5 \%$ gradient and steeper. Because of this the $m$ value of 0.5 was used to calculate the slope length. Finally, the LS factor with a spatial resolution of $30 \mathrm{~m}$ was generated from DEM using ArcGIS10.2.

\section{C-factor (land cover)}

The C-factor represents the land cover types such as cropland, vegetation, grassland, etc. and it describes how different land cover classes affect soil erosion (Wischmeier and Smith 1978). This factor is considered as the second soil erosion controlling factors (Farhan et al. 2013). The $C$ value of each land cover class was determined based on the value adapted to the Ethiopian condition (Table 1). The value of 0.15 is assigned for crop cover because the major crop type in the study area was cereal. The vegetative and grass cover were substantially improved in 2015. Therefore, for grassland a $C$ value of 0.05 (in 2010) and 0.01 (in 2015) and for vegetative cover 0.05 (in 2010) and 0.01 (in 2015) were assigned. For settlement a $C$ value of 0.005 was assigned. An increase in cover factors implies an increase in soil loss. Finally, two land cover maps with a cell size of $30 \mathrm{~m}$ were produced.

\section{P-factor (management practices)}

The P-factor refers to management practices such as terracing, mulching, strip cropping, contouring ploughing, and other protection measures, and its effect in reducing the amount and rate of runoff. In this study soil/ stone bunds and ploughing methods were considered to determine the P-factor for cropland because these are the dominant supportive management factors practiced to reduce soil erosion in the study area. Check dams, trenches and area enclosure were considered to determine the P value on non-cultivated land.

Information on the distribution of soil/stone bunds can be obtained using the automated terrace mapping model (which can map nearly $80 \%$ of the structures) developed by Mekuriaw et al. (2017). However, the bunds were digitized from high spatial resolution Google Earth picture to map all structures. We determined the $P$ value of the cropland using the value adapted to Ethiopian condition (Table 1). The P value on the cropland was 0.9 in 2010 and 0.6 in 2015 because effective conservation measures had been implemented and maintained properly since 2010. Similarly, the $P$ value of the vegetative cover was 0.55 in 2010 and 0.5 in 2015 because of improvement on vegetation cover in 2015 . The higher the P value, the more the soil erosion rate, and the vice versa.

\section{Results and discussions} Land cover change between 2010 and 2015

The land cover maps were created using supervised classification (Fig. 2). The error matrix in terms of sample counts and the areas of the map categories are shown in Table 2. 


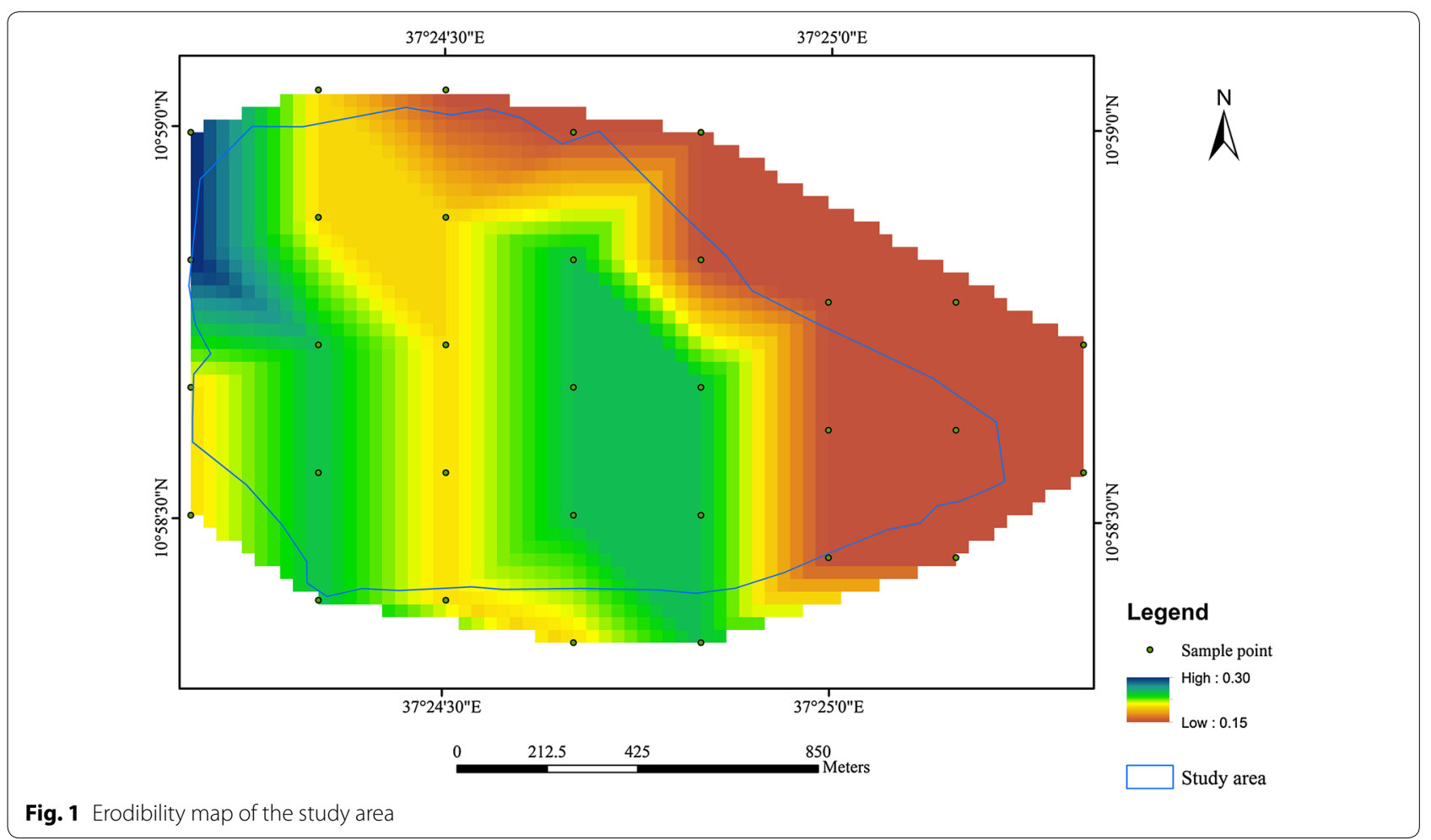

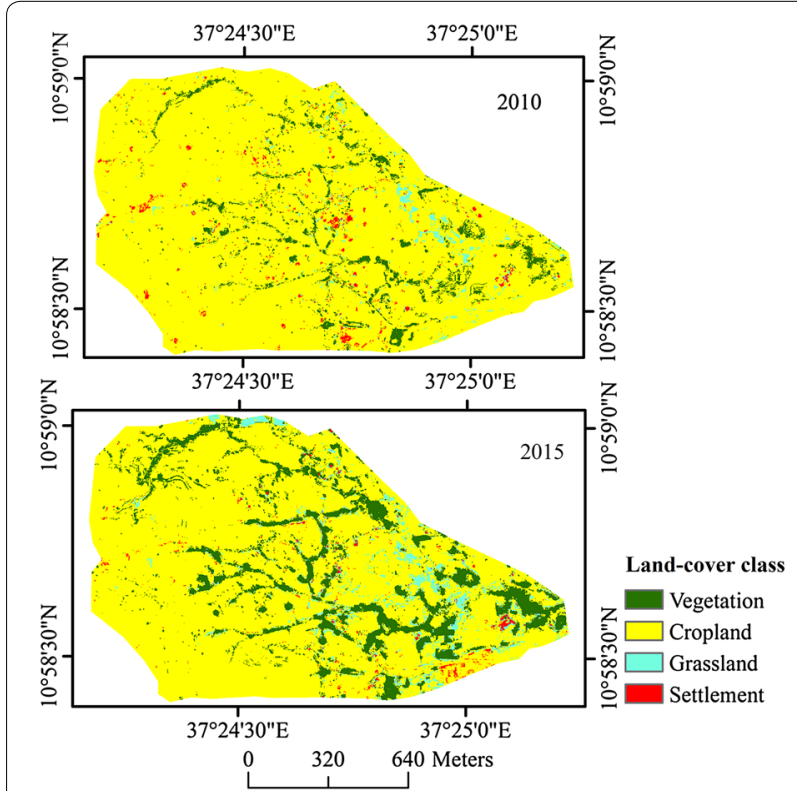

Fig. 2 Map showing the land covers type of the study area in 2010 and 2015

However, because of map classification error there was some variation between the area of land use/cover change obtained from a map and the true area (Olofsson et al. 2013). Therefore, the error matrix in terms of estimated area proportions, where accuracy can be computed directly, was calculated using Eq. 1 (Table 3). The overall classification accuracy was 96 and $95 \%$ for 2010 and 2015 land cover classes, respectively. Each land use class yields high users and producers accuracy (Table 3).

From the error matrix presented in Table 3, the proportion of each land use class, $\mathrm{Pj}$ (the column totals of the area proportion) was calculated based on the reference classification using Eq. 2 (Table 4). Then, the stratified estimator of the area of cropland, vegetation, grassland and settlement was obtained by multiplying the total mapped area (i.e. 155 ha) with the estimated area proportions (i.e. Pj) (Table 5). For example, the stratified estimator of cropland in 2010 is 155 ha* $0.903=140$ ha. However, the mapped area of cropland in 2010 is 144.1 ha. This indicates that 4.1 ha is added to the map from vegetation land but the error adjusted estimate of the area of cropland leaves this commissioned cropland areas.

To accept or reject the omission or commission error, the standard error and confidence interval of each land use class must be estimated. Therefore, the standard error of each land use class, $\mathrm{SE}(\mathrm{Pj})$, was calculated using Eq. 3 and presented in Table 4. Then the standard error of the adjusted area estimate was calculated as the product of the total mapped area (i.e. $155 \mathrm{ha}$ ) and $\mathrm{Pj}$ (Table 4). A $95 \%$ confidence interval $(Z=1.96)$ was used to assess 
Table 2 Error matrix of sample counts constructed from the accuracy assessment sample points

\begin{tabular}{|c|c|c|c|c|c|c|c|}
\hline Classes & 1 & 2 & 3 & 4 & Total & Mapped area (ha) & Wi \\
\hline \multicolumn{8}{|l|}{2010} \\
\hline 1 & 32 & 1 & 0 & 0 & 33 & 144.1 & 0.93 \\
\hline 2 & 0 & 13 & 1 & 0 & 14 & 7.2 & 0.05 \\
\hline 3 & 1 & 0 & 6 & 1 & 8 & 1.9 & 0.01 \\
\hline 4 & 0 & 1 & 0 & 9 & 10 & 1.8 & 0.01 \\
\hline Total & 33 & 15 & 7 & 10 & 65 & 155 & 1 \\
\hline \multicolumn{8}{|l|}{2015} \\
\hline 1 & 29 & 1 & 0 & 0 & 30 & 128.9 & 0.83 \\
\hline 2 & 2 & 15 & 0 & 0 & 17 & 20.0 & 0.13 \\
\hline 3 & 0 & 0 & 7 & 1 & 8 & 4.9 & 0.03 \\
\hline 4 & 0 & 0 & 2 & 8 & 10 & 1.2 & 0.01 \\
\hline Total & 31 & 16 & 9 & 9 & 65 & 155 & 1 \\
\hline
\end{tabular}

Classes 1 cropland, 2 vegetation, 3 grassland, 4 settlement. Rows and columns represent map and reference categories respectively

Table 3 Estimated error matrix based on Table 2 with cell entries expressed as the estimated proportion of area and accuracies

\begin{tabular}{|c|c|c|c|c|c|c|c|c|}
\hline Classes & 1 & 2 & 3 & 4 & wi & Mapped area (ha) & User's & Producers \\
\hline \multicolumn{9}{|l|}{2010} \\
\hline 1 & 0.902 & 0.028 & 0.000 & 0.000 & 0.93 & 144.1 & 0.97 & 0.99 \\
\hline 2 & 0.000 & 0.043 & 0.003 & 0.000 & 0.05 & 7.2 & 0.93 & 0.60 \\
\hline 3 & 0.001 & 0.000 & 0.009 & 0.002 & 0.01 & 1.9 & 0.75 & 0.73 \\
\hline 4 & 0.000 & 0.001 & 0.000 & 0.010 & 0.01 & 1.8 & 0.90 & 0.87 \\
\hline Total & 0.903 & 0.072 & 0.013 & 0.012 & 1.00 & 155 & & \\
\hline \multicolumn{9}{|l|}{2015} \\
\hline 1 & 0.804 & 0.028 & 0.000 & 0.000 & 0.83 & 128.9 & 0.96 & 0.98 \\
\hline 2 & 0.015 & 0.114 & 0.000 & 0.000 & 0.13 & 20.0 & 0.88 & 0.80 \\
\hline 3 & 0.000 & 0.000 & 0.028 & 0.004 & 0.03 & 4.9 & 0.87 & 0.94 \\
\hline 4 & 0.000 & 0.000 & 0.002 & 0.006 & 0.01 & 1.2 & 0.80 & 0.61 \\
\hline Total & 0.819 & 0.142 & 0.029 & 0.010 & 1.00 & 155 & - & - \\
\hline
\end{tabular}

1 cropland, 2 vegetation, 3 grassland, 4 settlement. Rows and columns represent map and reference categories respectively

Table 4 Estimate and confidence interval in 2010 and 2015

\begin{tabular}{llllrr}
\hline Classes & \multicolumn{2}{c}{ Proportion area } & $\begin{array}{l}\text { SE of adjusted } \\
\text { area (ha) }\end{array}$ & \multicolumn{2}{c}{$\begin{array}{l}\text { Confidence } \\
\text { interval (ha) }\end{array}$} \\
\hline 2010 & Pj & SE (Pj) & & 131.4 & 148.5 \\
Cropland & 0.903 & 0.0282 & 4.4 & 2.6 & 19.8 \\
Vegetation & 0.072 & 0.0284 & 4.4 & 0.7 & 3.1 \\
Grassland & 0.013 & 0.0039 & 0.6 & 1.4 & 2.4 \\
Settlement & 0.012 & 0.0016 & 0.25 & & \\
2015 & & & & 118.0 & 136.0 \\
Cropland & 0.819 & 0.0296 & 4.6 & 12.9 & 30.9 \\
Vegetation & 0.142 & 0.0296 & 4.6 & 4.1 & 4.9 \\
Grassland & 0.029 & 0.0013 & 0.2 & 1.2 & 2.0 \\
Settlement & 0.010 & 0.0013 & 0.2 & & \\
\hline
\end{tabular}

the accuracy of each land use class. Then the confidence interval for the estimated area of each land use class (A) was calculated as, $\mathrm{A}=\mathrm{Lj} \pm 1.96(\mathrm{SEi})$, where $\mathrm{Lj}$ refers estimated area of a given land use class and SEi is the standard error of the adjusted area estimate. For example, the confidence interval for the area of cropland in 2010 is 140 ha $\pm 4.4(1.96)=148.5$ ha (Table 4$)$.

The area of each land use/cover type calculated from a sample of reference observation was within the $95 \%$ confidence interval (Tables 4,5). Therefore, these data can be used for further analysis.

The results revealed that 5 years ago, 90 and $7 \%$ of the study area was covered by crop and vegetation respectively (Table 5). In 2015 cropland and vegetation covered 
Table 5 Area estimates of each land use class based on reference data (ha)

\begin{tabular}{|c|c|c|c|c|c|}
\hline \multirow[t]{2}{*}{ Classes } & \multicolumn{2}{|l|}{2010 (ha) } & \multicolumn{2}{|l|}{2015 (ha) } & \multirow{2}{*}{$\begin{array}{l}\text { Change } \\
\text { between } 2010 \\
\text { and } 2015(\%)\end{array}$} \\
\hline & Estimated & Mapped & Estimated & Mapped & \\
\hline Cropland & 140.0 & 144.1 & 127 & 128.9 & -9.2 \\
\hline Vegetation & 11.2 & 7.2 & 21.9 & 20.0 & +9.6 \\
\hline Grassland & 1.9 & 1.9 & 4.5 & 4.9 & +137 \\
\hline Settlement & 1.9 & 1.8 & 1.6 & 1.2 & -16 \\
\hline Total & 155 & 155 & 155 & 155 & - \\
\hline
\end{tabular}

82 and $15 \%$ of the study area. However, over the last 5 years substantial amount of cropland was converted to vegetation and grassland.

\section{Cropland}

The total area of cropland in 2010 and 2015 was 90 and $82 \%$, respectively. This land use type decreased by $9 \%$ over the last 5 years mainly attributed to the change of land use from cropland to vegetation area (the biological measures planted to support soil bunds), and to grassland. Contrary to above finding, studies conducted in different parts of Ethiopia indicated that land use has undergone substantial changes, mainly increase in cropland due to population growth (Moges and Holden 2009; Garedew et al. 2009). Moreover, local elder respondents confirmed that 24 years ago, the population was small and that there was enough cultivated land. However, cultivated land has become scare after the 1995/1996 regional land redistribution because of rapid human population growth. At present, cropland reduced substantially and thus the newly formed landless households were migrated to other parts of the country.

\section{Vegetation}

Results showed that the vegetation cover was 11.2 ha in 2010 and 22 ha in 2015. Elderly farmers reported that the vegetative cover in their area had declined before 2010 since all farmers had unrestricted access rights to the available vegetation resources-confirming the earlier findings of Mekuriaw (2006). However, over the last 5 years the vegetative cover increased by $95 \%$ (Table 5 ). It may be attributed to (1) more importantly; since 2010 farmers have planted and maintained biological measures e.g., Sesbania sesban on the constructed soil bunds and gulley sides (Fig. 3a, b), and (2) many homesteads have planted eucalyptus as eucalyptus trees have become a profitable business (e.g. sources of wood for construction material, farm implements, fire wood, and cash crop). Similarly, $88 \%$ of the respondents reported the improvement of vegetative cover mainly due to the biological measures adopted on the soil bund (Table 6).

\section{Grassland}

The grassland cover of the study area was 1.9 and 4.5 ha in 2010 and 2015, respectively. This land use type had increased by $137 \%$ over the last 5 years. This is because (1) more importantly because of low crop yield, some land holdings were changed to grassland, and (2) each farmer who owned livestock left part of cropland for grassland which is used for grazing land and also as source of forage.
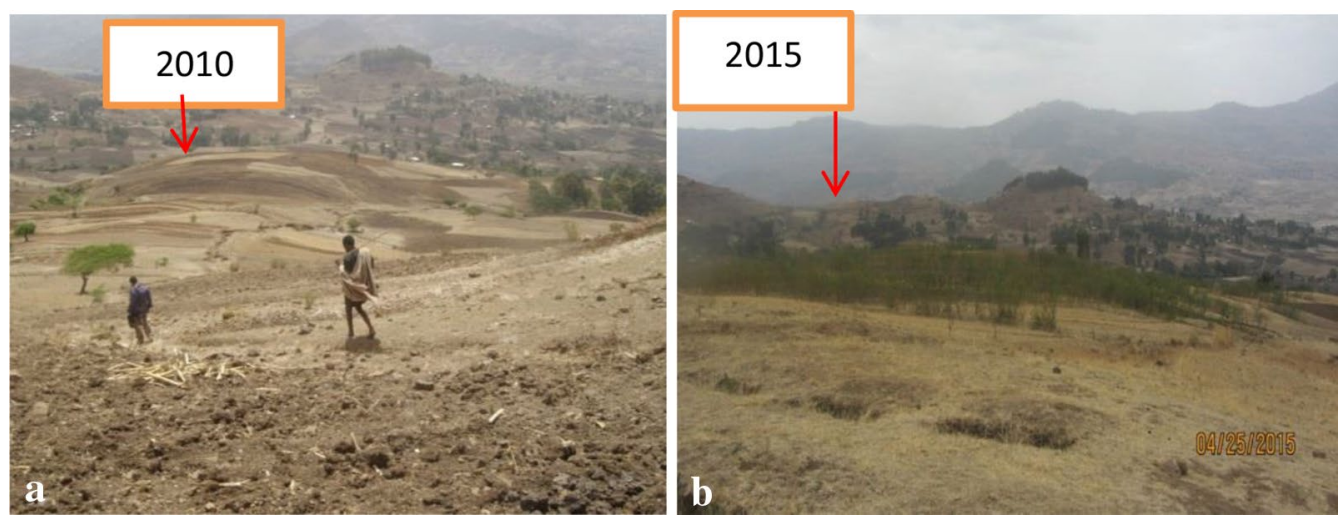

Fig. 3 Vegetation cover on the cropland of the study area in 2010 (a) and 2015 (b) 
Table 6 Farmers' perception of the vegetation covers in the study area $(\mathrm{N}=121)$

\begin{tabular}{lc}
\hline $\begin{array}{l}\text { Status of vegetation cover } \\
\text { between } \mathbf{2 0 1 0} \text { and } \mathbf{2 0 1 5}\end{array}$ & \% of respondents \\
\hline Increased & 88 \\
No change & 5 \\
Decreased & 7 \\
Total & 100 \\
\hline
\end{tabular}

\section{Settlement}

Settlements covered a total area of 1.9 ha in 2010 and 1.6 ha in 2015 . This meant the area is decreased by 0.3 ha between 2010 and 2015 .

\section{Soil loss rate of the study area in 2010 and 2015}

After preparing each information layer (erosivity, erodibility, slope length and gradient, land cover and management factors), they were multiplied into the specified cells using ArcGIS 10.2. Then, the soil erosion rate map was developed which revealing an annual average soil loss of the study area (Fig. 4).

Average soil loss rate in the study area was 19.2 $\mathrm{Mg} \mathrm{ha}^{-1}$ year $^{-1}$ in 2010 and $12.4 \mathrm{Mg} \mathrm{ha}^{-1}$ year $^{-1}$ in 2015 (Table 7). The annual soil loss ranged between $0-264 \mathrm{Mg} \mathrm{ha}^{-1}$ year $^{-1}$ in 2010 and 0-176 $\mathrm{Mg} \mathrm{ha}^{-1}$ year $^{-1}$ in 2015. The highest annual soil loss was observed on the steep slope compared to similar land uses on flat land. Farhan et al. (2013) found high soil erosion in areas where there is sparse vegetation cover and poor soil conservation measures.

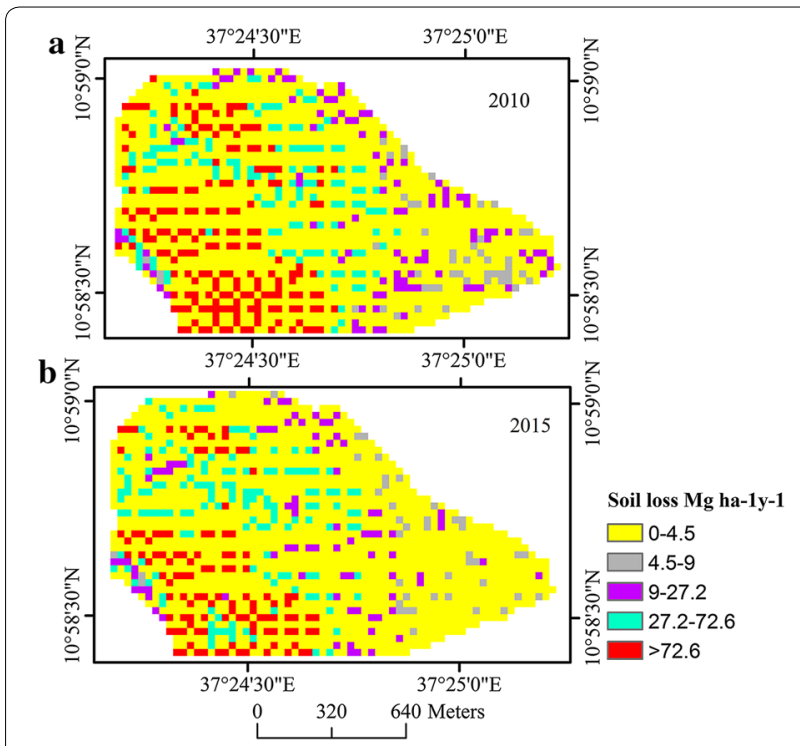

Fig. 4 Soil loss rate map of the study area in 2010 (a) and 2015 (b)
Table 7 Annual soil loss rate in 2010 and 2015

\begin{tabular}{|c|c|c|c|c|}
\hline \multirow{3}{*}{$\begin{array}{l}\text { Soil loss class } \\
\left(\mathrm{Mg} \mathrm{ha}^{-1}\right. \\
\left.\text { year }^{-1}\right)\end{array}$} & \multicolumn{4}{|c|}{ Soil loss in 2010 and 2015} \\
\hline & \multicolumn{2}{|l|}{2010} & \multicolumn{2}{|l|}{2015} \\
\hline & Area (ha) & $\begin{array}{l}\text { Soil loss } \\
\left(\mathrm{Mg} \mathrm{ha}^{-1}\right. \\
\left.\text { year }^{-1}\right)\end{array}$ & Area (ha) & $\begin{array}{l}\text { Soil loss } \\
\left(\mathrm{Mg} \mathrm{ha}^{-1}\right. \\
\left.\text { year }^{-1}\right)\end{array}$ \\
\hline $0-4.5$ & 112.9 & 108.7 & 120.3 & 119.1 \\
\hline $4.5-9.0$ & 4.6 & 31.7 & 3.8 & 27.8 \\
\hline $9.0-27.2$ & 9.0 & 151.7 & 7.8 & 138.9 \\
\hline $27.2-72.6$ & 12.6 & 619.6 & 13.5 & 645.9 \\
\hline$>72.6$ & 15.9 & 2070.1 & 9.6 & 988.6 \\
\hline Total & 155 & 2981.8 & 155 & 1920.2 \\
\hline Average & 21.2 & & 13.7 & \\
\hline
\end{tabular}

However, over the last 5 years the soil loss rate decreased by $54.7 \%$. This is due to different soil conservation interventions implemented in the study area in the last 5 years. Soil loss rates decreased exponentially as vegetation cover increases (Gyssels et al. 2005). Conservation measures reduced the kinetic energy of raindrops, reducing detachment and transportation of soils. Similarly, Adimassu et al. (2014) found that in the central highlands of Ethiopia after 3 years the constructed soil bund were able to reduce the average soil loss rate by $47 \%$. The farmers revealed that after practicing the conservation measures less soil erosion was observed in the study area as compared to before the intervention. Hurni (1985) indicated that soil and water conservation intervention reduced soil loss, increased soil moisture and fertility which enhance the availability of vegetation covers.

Effect of land management on socio-economic conditions As mentioned earlier, crop production and livestock husbandry were the main source of income in the study area. Therefore, to identify the direct and indirect impact of soil bund, Sesbania sesban plantation, trenches and check dams practiced in the study area farmers were asked about the benefit that they are obtaining from these measures (Table 8).

Seventy-four per cent farmers indicated that crop productivity was increased since 2012 because of the conservation measures being practiced and maintained in the study area. They indicated that the fertility of the soil improved and crop yield increased. However, $17 \%$ of the farmers did not observe any change on crop yield. Nearly all of the respondents reported that the soil and water conservation structures were highly effective (i.e. were able to keep the soil in place). This confirmed that the management measures implemented are contributing for the improvement of crop yield. Well managed soil contributed a lot for food security in agrarian countries (Keesstra et al. 2016). Although the 
Table 8 Farmers' perceptions for crop yield and soil and water conservation structures in the study area in $\mathbf{2 0 1 0}$ and $2015(\mathrm{~N}=121)$

\begin{tabular}{lc}
\hline $\begin{array}{l}\text { Response } \\
\text { Crop yield per hectare }\end{array}$ & $\begin{array}{c}\text { \% of respondents } \\
\text { Between 2010 and 2015 }\end{array}$ \\
\hline Increased & 74 \\
Decreased & 1 \\
No change & 17 \\
Do you practice SWC structures? & 100 \\
Yes & 0 \\
No & \\
Performance of SWC structures & 97 \\
Highly effective & 3 \\
Moderately effective & 0 \\
Not effective & \\
\hline
\end{tabular}

economic returns of soil bund, plantation, etc. takes longtime, farmers of the study area acknowledge its benefit. Similarly, Ayalew (2011) found that in the highlands of southern Ethiopia, crop yields increased by $22 \%$ on some farms within 1 year of soil bund construction. Studies examining the impacts of soil and water conservation structures indicated that the structures have benefited productivity, crop yield increased by an average of $23 \%$ (Pender and Gebremedhin 2006; Brhane and Mekonen 2009) and by about $42 \%$ (Benin 2006). Moreover, a study conducted in the Ethiopian Highlands showed that the constructed physical soil and water conservation structures improved the productivity of the land after 7 years (Schmidt and Tadesse 2012).

Farmers also reported that Sesbania sesban planted to support the soil bund provides additional forage to sustain livestock which is the second main source of income. It was also confirmed by Brhane and Mekonen (2009) that vegetation cover and forage availability were improved after practicing and maintaining soil and water conservation structures.

In addition to the quantified soil loss and vegetative cover data, measured data (e.g. crop yield per hectare, amount of forage per meter of soil bund, etc.) is necessary to discuss in detail about the impact of land resources management on the livelihood of the population. However, based on the qualitative information collected from the farmers it is possible to say that the land resources management measures practiced in study area has substantial positive impact (e.g., increasing crop yield, source of forage for livestock, etc.) on the livelihood of the population.

\section{Conclusions}

It may be concluded from this study that the land resources management measures practiced in the study area were effectively improving the vegetative cover, reducing soil loss, improving crop yield and becoming main source of forage for livestock. In addition, the land management measures have substantially contributed to the improvement of the livelihood of the population. Therefore, bottom-up land resource management approach can be considered as an effective strategy in other areas of Ethiopia where issues of unsustainability could be better addressed.

\section{Author details \\ ${ }^{1}$ Natural Resources Management Department, Bahir Dar University, Bahir Dar, P. O. Box 1739, Bahir Dar, Ethiopia. ${ }^{2}$ Geospatial Data and Technology Center, Bahir Dar University, Bahir Dar, P. O. Box 1739, Bahir Dar, Ethiopia.}

\section{Acknowledgements}

The full cost of this study was covered by the Geospatial Data and Technology Center (GDTC), Bahir Dar University, Ethiopia. The grant number is GDTC03. I am thankful for this generous financial assistance. Comments from two anonymous referees improved the quality of the original manuscript.

\section{Competing interests}

The authors declare that they have no competing interests.

\section{Publisher's Note}

Springer Nature remains neutral with regard to jurisdictional claims in published maps and institutional affiliations.

Received: 6 July 2016 Accepted: 5 June 2017

Published online: 14 June 2017

\section{References}

Adimassu Z, Mekonnen K, Yirga C, Kessler A (2014) Effect of soil bunds on runoff, soil and nutrient losses, and crop yield in the central highlands of Ethiopia. Land Degrad Dev 25(6):554-564. doi:10.1002/ldr.2182

Amdihun A, Gebremariam E, Rebelo L, Zeleke G (2014) Suitability and scenario modeling to support soil and water conservation interventions in the Blue Nile Basin, Ethiopia. Environ Sys Res 3:1-13

Asrat P, Belay K, Hamito D (2004) Determinants of farmers' willingness to pay for soil conservation practices in the southeastern highlands of Ethiopia. Land Degrad Dev 15:423-438. doi:10.1002/Idr.623

Ayalew A (2011) Construction of soil conservation structures for improvement of crops and soil productivity in the southern Ethiopia. J Environ Earth Sci $1: 21-29$

Benin S (2006) Policies and programs affecting land management practices, input use, and productivity in the highlands of Amhara Region, Ethiopia. In: Pender J, Place F, Ehui S (eds) Strategies for sustainable land management in the east african highlands. Blackwell Publishing, Washington DC, pp 217-256

Brhane G, Mekonen K (2009) Estimating soil loss using universal soil loss equation (USLE) for soil conservation planning at Medego Watershed, Northern Ethiopia. J Am Sci 5(1):58-69

Byrne K (2001) Environmental science 2nd edition. Cheltenham, UK

Cochran W (1977) Sampling techniques, 3rd edn. Wiley, New York

De Graaff J, AkliluAmsalu Bodnar F, Kessler A, Posthumus H, Tenge A (2008) Factors influencing adoption and continued use of long-term soil and water conservation measures in four developing countries. Appl Geogr 28:271-280. doi:10.1016/j.apgeog.2008.05.001

Farhan Y, Zregat D, Farhan I (2013) Spatial estimation of soil erosion risk using RUSLE approach, RS, and GIS techniques: a case study of Kufranja Watershed, Northern Jordan. J Wat Resour Prot 5:1247-1261. doi:10.4236/ jwarp.2013.512134

Garedew E, Sandewall M, Söderberg U, Campbell BM (2009) Land-use and land-cover dynamics in the central rift valley of Ethiopia. Environ Manag 44:683-694. doi:10.1007/s00267-009-9355-z 
GFOI (2013) Integrating remote-sensing and ground-based observations for estimation of emissions and removals of greenhouse gases in forests: methods and guidance from the global forest observations initiative. Pub: Group on Earth Observations, Geneva, p 2014

Gyssels G, Poesen J, Bochet E, Li Y (2005) Impact of plant roots on the resistance of soils to erosion by water: a review. Prog Phys Geogr 29(2):189-217

Hailu B (2015) Econometrics model on determinants of adoption and continued use of improved soil and water conservation practices: the case of Boloso-Sore Woreda of Wolaita Zone, Ethiopia. J Sci Res Essent 4(2):35-42

Hurni H (1985) Erosion-productivity-conservation systems in Ethiopia. Paper presented at the 4th international conference on soil conservation, Maracacy, Venezuela, 3-9 November 1985

Hurni H, Abate S, Bantider A, Debele B, Ludi E, Portner B, Yitaferu B, Zeleke G (2010) Land degradation and sustainable land management in the Highlands of Ethiopia. In: Hurni H, Wiesmann U, editors. With an international group of co-editors. Global Change and Sustainable Development: A Synthesis of Regional Experiences from Research Partnerships. Perspectives of the Swiss National Centre of Competence in Research (NCCR) North-South, University of Bern, Vol. 5. Bern, Geographica Bernensia. p 187-207

Hurni K, Zeleke G, Kassie M, Tegegne B, Kassawmar T, Teferi E, Moges A, Tadesse D, Ahmed M, Degu Y, Kebebew Z (2015) Soil degradation and sustainable land management in the rainfed agricultural areas of Ethiopia: an assessment of the economic implications. Report for the economics of land degradation initiative

Keesstra SD, Bouma J, Wallinga J, Tittonell P, Smith P, Cerdà A, Montanarella L, Quinton JN, Pachepsky Y, van der Putten WH, Bardgett RD, Moolenaar S, Mol G, Jansen B, Fresco LO (2016) The significance of soils and soil science towards realization of the United Nations Sustainable 1 Development Goals. Soil 2(2):111-128. doi:10.5194/soil-2-111-2016

Mekuriaw A (2006) The role of land-use on impacts of drought in Shebel Berenta Wereda, Amhara National Regional State, Ethiopia: A Case Study in Kutkwat Sekela Catchment. Addis Ababa University, Addis Ababa

Mekuriaw A, Hurni H (2015) Analysing factors determining the adoption of environmental management measures on the highlands of Ethiopia. Civil Environ Res 7:61-72

Mekuriaw A, Heinimann A, Gete Z, Hans H, Kaspar H (2017) An automated method for mapping physical soil and water conservation structures on cultivated land using GIS and remote sensing techniques. J Geogr Sci 27(1):79-94. doi:10.1007/s11442-017-1365-9
MoFED (Ministry of Finance and Economic Development) (2010) Growth and transformation plan, 2010/11-2014/15, Volume I: main text. Addis Ababa

Moges A, Holden MN (2009) Land-covers change and gully development between 1965 and 2000 in Umubulo catchement, Ethiopia. Mt Res Dev 29:265-276. doi:10.1659/mrd.00015

MoNRDEP (Ministry of Natural Resources Development and Environmental Protection National) (1994) Conservation strategy of Ethiopia, Volume I: National policy on the resources base, its utilization and planning for sustainability. Addis Ababa

Oinam BC, Marx W, Scholten T, Wieprecht S (2014) A fuzzy rule base approach for developing a soil protection Index map: a case study in the upper awash basin, Ethiopian Highlands. Land Degrad Dev 25:483-500. doi:10.1002/ldr.2166

Olofsson P, Foody G, Stehman S, Woodcock C (2013) Making better use of accuracy data in land change studies: estimating accuracy and area and quantifying uncertainty using stratified estimation. Remote Sens Environ 129(2013):122-131

Pender J, Gebremedhin B (2006) Land management, crop production, and household income in the highlands of Tigray, Northern Ethiopia: an econometric analysis. In: Pender J, Place F, Ehui S (eds) Strategies for sustainable land management in the east African highlands. Blackwell Publishing, Washington DC, pp 107-140

Renard KG, Forster GR, Weesies GA, McCool DK, Yoder DC (1997) Predicting soil erosion by water: a guide to conservation planning with the revised universal soil loss equation (RUSLE). US Department of Agriculture, Agriculture Handbook No. 703

Schmidt E, Tadesse F (2012) Household and plot Level impact of sustainable land and watershed management (SLWM) practices in the Blue Nile. Ethiopia Strategy Support Program II (ESSP II) Working Paper 42. http:// www.ifpri.org/sites/default/files/publications/esspwp42.pdf. Accessed 21 Dec 2013

Sisay A, Chalie N, Girmay Z, Takele G, Tolera A (2014) Landscape-scale soil erosion modeling and risk mapping of mountainous areas in eastern escarpment of Wondo Genet watershed, Ethiopia. Int Res J Agric Sci Soil Sci 4(6):107-116

Wischmeier W, Smith D (1978) Predicting rainfall erosion losses: a guide to conservation planning. US Department of Agriculture, Agriculture Handbook No. 537

\section{Submit your manuscript to a SpringerOpen ${ }^{\circ}$ journal and benefit from:}

- Convenient online submission

- Rigorous peer review

- Open access: articles freely available online

- High visibility within the field

Retaining the copyright to your article

Submit your next manuscript at springeropen.com 